\title{
Corrosion and protection of metals in the rural atmosphere of "El Pardo", Spain (PATINA / CYTED project)
}

\author{
J. Simancas*, J.G. Castaño** and M. Morcillo*
}

\begin{abstract}
Atmospheric corrosion tests of metallic and organic coatings on steel, zinc and aluminium have been conducted in "El Pardo" (Spain) as part of the PATINA/CYTED project "Anticorrosive Protection of Metals in the Atmosphere". This is a rural atmosphere with the following ISO corrosivity categories: $\mathrm{C} 2(\mathrm{Fe}), \mathrm{C} 2(\mathrm{Zn}), \mathrm{C} 3(\mathrm{Cu})$ and $\mathrm{C} 1(\mathrm{Al})$. Its average temperature and relative humidity is $13^{\circ} \mathrm{C}$ and $62.8 \%$, respectively, and it has low $\mathrm{SO}_{2}$ and $\mathrm{Cl}^{-}$contents. Results of 42 months exposure are discussed. Atmospheric exposure tests were carried out for the following types of coatings: conventional paint coatings for steel and hot-dip galvanized steel (group 1), new painting technologies for steel and galvanized steel (group 2), zinc-base metallic coatings (group 3), aluminium-base metallic coatings (group 4), coatings on aluminium (group 5) and coil-coatings on steel, hot-dip galvanized steel and $55 \% \mathrm{Al}$-Zn coated steel (group 6).
\end{abstract}

Keywords Atmospheric corrosion. Organic coatings. Metallic coatings.

\section{Corrosión y protección de metales en la atmósfera rural de “El Pardo", España (Proyecto PATINA / CYTED)}

\begin{abstract}
Resumen Como parte del proyecto PATINA/CYTED "Protección anticorrosiva de metales en la atmósfera" se han llevado a cabo en la estación de ensayo de "El Pardo" (España), ensayos de corrosión atmosférica de recubrimientos metálicos y orgánicos sobre acero, zinc y aluminio. Se trata de una atmósfera rural según la clasificación ISO de grado de corrosividad: C2 ( $\mathrm{Fe}), \mathrm{C} 2(\mathrm{Zn}), \mathrm{C} 3(\mathrm{Cu})$ y $\mathrm{C} 1(\mathrm{Al})$. La temperatura y humedad relativa media es de $13{ }^{\circ} \mathrm{C}$ y $62,8 \%$, respectivamente, y tiene bajos contenidos de $\mathrm{SO}_{2}$ y $\mathrm{Cl}^{-}$. Se discuten los resultados obtenidos después de 42 meses de exposición. Los ensayos de corrosión atmosférica se llevaron a cabo para tres tipos de recubrimientos: recubrimientos de pintura convencional sobre acero y acero zincado (grupo 1), nuevas tecnologías en pinturas para acero y acero galvanizado (grupo 2), recubrimientos metálicos base zinc (grupo 3), recubrimientos metálicos base aluminio (grupo 4), recubrimientos sobre aluminio (grupo 5) y recubrimientos de banda en continuo sobre acero, acero galvanizado y acero recubierto con $55 \% \mathrm{Al}-\mathrm{Zn}$ (grupo 6).
\end{abstract}

Palabras clave Corrosión atmosférica. Recubrimientos orgánicos. Recubrimientos metálicos.

\section{INTRODUCTION}

Different means have been developed, including the use of protective coatings, to protect materials from the degradation they suffer when exposed to the atmosphere for certain lengths of time. Due to the large number of industrial applications and situations that can arise in practice, the simulation of natural exposure tests ${ }^{[1-5]}$, though slow and costly, can be of great value. Constant changes in coatings technology, as a result of the appearance of new coatings with improved characteristics and properties, justifies the performance of studies such as that presented here.

(*) Centro Nacional de Investigaciones Metalúrgicas (CENIM), Consejo Superior de Investigaciones Científicas (CSIC), Avda. Gregorio del Amo, 8. 28040 Madrid (España).

(**) Grupo de Corrosión y Protección. Universidad de Antioquia, Medellín, Colombia. 
The present work forms part of an ambitious project entitled "Anticorrosive Protection of Metals in the Atmosphere" (PATINA/Thematic Network XV.D - CYTED). The experimentation phase was carried out in a network of atmospheric corrosion stations in the Ibero-American area, considering a broad range of environments and corrosivities ${ }^{[6]}$. The station at "El Pardo" (Madrid, Spain) forms part of this network and is classified as a rural atmosphere, according to ISO $9223^{[7]}$, with the following corrosivity categories: $\mathrm{C} 2(\mathrm{Fe})$, $\mathrm{C} 2(\mathrm{Zn}), \mathrm{C} 3(\mathrm{Cu})$ and $\mathrm{C} 1(\mathrm{Al})$. The average temperature is $13^{\circ} \mathrm{C}$, the average relative humidity $62.8 \%$ and the $\mathrm{SO}_{2}$ and $\mathrm{Cl}$ contents recorded are low. Specimens belonging to the six working groups comprising the project (see Table I) were first exposed in the early months of 1996, arranged in two special racks.

\section{EXPERIMENTAL PROCEDURE}

The test specimens were in some cases supplied by the manufacturer and in other cases, such as the materials with organic coatings, prepared in the laboratory following the corresponding specifications.

On a significant number of the specimens an incision was made in the coatings, penetrating to the base metal, in order to determine the behaviour and delamination of the system in unprotected zones. The coatings were evaluated at periodic intervals during the exposure time (42 months) following the ISO standards selected for that purpose ${ }^{[8 \text { and } 9]}$.

In view of the amount of specimens and the variety of coatings exposed in the atmospheric testing station at "El Pardo", a summary is presented below for each group. More detailed information about the characteristics of the coatings has been reported elsewhere ${ }^{[6]}$.

Table I. Groups of specimens exposed in "El Pardo" station

Tabla I. Grupos de probetas expuestas en la estación de "El Pardo"

\begin{tabular}{ll}
\hline Group & \multicolumn{1}{c}{ Denomination } \\
\hline 1 & Conventional paints on steel and hot dip galvanized steel \\
2 & Advanced paints on steel and zinc coated steel \\
3 & Zinc base coatings \\
4 & Aluminium base coatings \\
5 & Coatings on aluminium \\
6 & Coil coatings \\
\hline
\end{tabular}

- GROUP 1: Conventional paint coatings were studied on steel and galvanized steel specimens of $125 \times 250 \mathrm{~mm}$. The paint schemes and average thicknesses were grouped by code number/paint scheme/average thickness. Thus the schemes applied on carbon steel were: 1-4/alkyd-linseed primer with alkyd-soya topcoat/67-135 $\mu \mathrm{m}$; 5-8/epoxy, ethyl silicate systems with polyurethane topcoats/110-160 $\mu \mathrm{m}$; and $9 /$ chlorinated rubber $/ 110 \mu \mathrm{m}$. The denominations $\mathrm{A}$ and $\mathrm{B}$ refer to low and high thicknesses respectively. The coatings on galvanized steel base specimens, $G$, consisted of systems based on a wash-primer, primer and topcoat: $1 /$ polyvinylbutane with alkyd-soya/90. $95 \mu \mathrm{m}$; system 2 differed to the former in that the wash-primer is epoxy-isocyanate, with the same primer and topcoat/105 $\mu \mathrm{m}$; 3/polyvinylbutane, epoxy-amine, polyurethane/ $140 \mu \mathrm{m}$; 4/epoxy primer, polyurethane topcoat/ $105 \mu \mathrm{m}$; 5/polyvinylbutane with alkyd primer and topcoat; 6/epoxy-isocyanate with chlorinated rubber primer and topcoat $/ 117 \mu \mathrm{m}$. These average thicknesses do not include the thickness of the galvanizing $(60 \mathrm{~mm})$. All the specimens have edge protection and include an incision.

- GROUP 2: Organic coatings (new technologies) were tested on a total of 25 steel and galvanized steel specimens of $125 \times 250 \times 2 \mathrm{~mm}$. Incisions were made and edge protection provided on all the specimens prior to their exposure. The paint schemes in this group, denominated by code number/general description/thickness, were: 1-8/water base systems (acrylic, epoxy)/194-342 $\mu \mathrm{m}$; 9-15/special pretreatments (epoxy-polyester, polyester)/68-85 $\mu \mathrm{m} ; 16-19 /$ high solids (epoxy, epoxy/polyurethane)/73-84 $\mu \mathrm{m}$; 20-22/on galvanized steel (phosphatizing- epoxy/ polyester)/140-365 $\mu \mathrm{m}$.

- GROUP 3: 54 specimens with zinc coatings were exposed, of dimensions $100 \times 150 \times 1 \mathrm{~mm} .18$ specimens were withdrawn each year for laboratory tests. They are grouped into five materials with different $\mathrm{Zn}$ coatings on steel: 1/Galvanized $\quad(60 \mathrm{~mm}) ; \quad$ 2/Metallized; 3/Electrodeposited zinc $\left(90 \mathrm{~g} / \mathrm{m}^{2}\right)$; $4 /$ Sendzimir $(66-22 \mathrm{~m}) ; 5 / \mathrm{Galfan}(5 \% \mathrm{Al})$. One third of the specimens in this group included incisions.

- GROUP 4: A total of 16 specimens have been tested with aluminium coatings, of dimensions $100 \times 150 \mathrm{~mm}$, distributed in the following way: A/Aluminized $(40 \mathrm{~mm})$; B/Metallized with $\mathrm{Al}$ 
(150 mm); C/Metallized with Al/Zn (150 mm); $\mathrm{D} /$ Galvalume $(\mathrm{Al} / \mathrm{Zn}+\mathrm{Si})(20 \mathrm{~mm})$. Four specimens included an incision.

- GROUP 5: This group comprised 32 aluminium base specimens of dimensions $100 \times 150 \mathrm{~mm}$, distributed in the following way: 25 of anodized aluminium and 7 of lacquered aluminium. During the 42 months of experimentation anodized specimens were withdrawn each year. All the specimens were inspected periodically. The tested specimens were: 1) Bare aluminium specimens, 2) Anodized aluminium with coating thicknesses of 5, 15 and $25 \mu \mathrm{m}$, and 3) Painted aluminium: ALA/Powder paint: polyester $(110 \mu \mathrm{m})$ and ALB /Liquid paint: acrylic $(45 \mu \mathrm{m})$, both from Spain, and ALC/Conventional: wash primer/alkyd (130 $\mu \mathrm{m})$, from Cuba. The lacquered aluminium specimens were exposed with and without an incision.

- GROUP 6: 24 specimens of dimensions $100 \times 150 \mathrm{~mm}$ were exposed with different coil coatings. The specimens with an incision were identified by even numbers and those without an incision by odd numbers. The characteristics of the Group 6 specimens are differentiated by their origin: Argentina, code numbers A1-A6, with Galvalume base and epoxy/polyester and polyester/polyvinyl coatings $(43 \mu \mathrm{m})$ had edge protection by means of epoxy-bituminous paint; CH1 to 2, prepared in Chile, steel with epoxy/polyester topcoat $(30 \mu \mathrm{m})$, and ES1 to 4 , manufactured in Spain: galvanized with polyurethane/polyester coating, melamine alkyd epoxy (40-70 $\mu \mathrm{m})$. These average thicknesses include the metallic coating.

\section{RESULTS AND DISCUSSION}

The results presented below indicate the defects found after 42 months of experimentation in "El
Pardo" testing station. The periodic evaluations of the state and deterioration of the paint coatings were carried out by visual inspection and comparison with ISO standards ${ }^{[8 \text { and } 9]}$.

- GROUP 1: Table II schematizes the results of the evaluations of colour, chalking, blistering in incisions and fungus. The changes in colour, chalking and blistering in the incisions are slight. Fungus are observed on all the specimens except for $1 \mathrm{~Gb}$, and are easily removed by cleaning with water. The degree of deterioration in this group is fairly slight (grade 1 to 2) and is related with the surface appearance.

- GROUP 2: Some defects were found, as shown in table III. The start of some small blistering is observed along the incision, as well as chalking and a slight loss of colour. The presence of fungus is fairly severe on some specimens, though these are easily removed with water. The degree of deterioration is also very slight.

- GROUP 3: Of the inspected specimens, attention is drawn to the details indicated in table IV. The protection afforded by the $\mathrm{Zn}$ base metallic coatings is good.

- GROUP 4: Of the inspected specimens, attention is drawn to the following main details: corrosion at edges $(\mathrm{A}, \mathrm{B}, \mathrm{C})$ and corrosion in the incision (B), also noting good behaviour of the metallized coating with $\mathrm{Al} / \mathrm{Zn}$ during the 42 months of testing (Table $\mathrm{V}$ ). The protection afforded by the aluminium base metallic coatings is good.

- GROUP 5: The observations referring to the specimens in this group are summarized in table VI. The deterioration encountered is also very low. Only in type $\mathrm{C}$ lacquered specimens is a large amount of fungus observed.

- GROUP 6: Table VII schematizes the results of the evaluations made on the specimens in this

Table II. Defects encountered on Group 1 specimens after 42 months of exposure in "El Pardo" testing station Tabla II. Defectos encontrados en las probetas del Grupo 1 después de 42 meses de exposición en la estación de "El Pardo"

\begin{tabular}{|c|c|c|c|c|c|c|c|c|c|c|c|c|c|c|c|c|}
\hline \multirow{2}{*}{ Defects } & \multicolumn{15}{|c|}{ Identification of paint systems/Degree of deterioration (ISO) } & \multirow[b]{2}{*}{$6 \mathrm{G}$} \\
\hline & 1 & 2 & 3 & 4 & 5 & 6 & 7 & 8 & 9 & 10 & $1 \mathrm{G}$ & $2 \mathrm{G}$ & $3 G$ & 4G & $5 G$ & \\
\hline Colour & 1 & 1 & 1 & 1 & 0 & 0 & 0 & 0 & 1 & 1 & 1 & 1 & 0 & 1 & 1 & 1 \\
\hline Chalking & 1 & 1 & 1 & 1 & 1 & 1 & 0 & 1 & 2 & 1 & 2 & 1 & 1 & 1 & 1 & 2 \\
\hline Incision (blist.) & 0 & 0 & 0 & 1 & 2 & 0 & 0 & 1 & 2 & 1 & 0 & 0 & 0 & 0 & 0 & 0 \\
\hline Fungus & 1 & 1 & 3 & 4 & 0 & 0 & 0 & 1 & 1 & 1 & 1 & 1 & 0 & 1 & 1 & 1 \\
\hline
\end{tabular}


Corrosion and protection of metals in the rural atmosphere of "El Pardo", Spain (PATINA / CYTED project)

J. Simancas, J.G. CASTAÑo AND M. Morcillo

Table III. Defects encountered on Group 2 specimens after 42 months of exposure in "El Pardo" testing station

Tabla III. Defectos encontrados en las probetas del Grupo 2 después de 42 meses de exposición en la estación de "El Pardo"

\begin{tabular}{lllllllllllllllllllllllllll}
\hline \multirow{1}{*}{ Defects } & \multicolumn{11}{c|}{ Identification of paint systems/Degree of deterioration (ISO) } \\
\cline { 2 - 4 } & $\mathbf{1}$ & $\mathbf{2}$ & $\mathbf{3}$ & $\mathbf{4}$ & $\mathbf{5}$ & $\mathbf{6}$ & $\mathbf{7}$ & $\mathbf{8}$ & $\mathbf{9}$ & $\mathbf{1 0}$ & $\mathbf{1 1}$ & $\mathbf{1 2}$ & $\mathbf{1 3}$ & $\mathbf{1 4}$ & $\mathbf{1 5}$ & $\mathbf{1 6}$ & $\mathbf{1 7}$ & $\mathbf{1 8}$ & $\mathbf{1 9}$ & $\mathbf{2 0}$ & $\mathbf{2 1}$ & $\mathbf{2 2}$ \\
\hline Colour & 0 & 0 & 1 & 0 & 1 & 0 & 0 & 0 & 1 & 1 & 1 & 1 & 1 & 1 & 1 & 1 & 1 & 1 & 1 & 0 & 0 & 0 \\
Shine & 0 & 0 & 0 & 3 & 0 & 3 & 3 & 3 & 0 & 0 & 0 & 0 & 0 & 0 & 0 & 0 & 0 & 0 & 0 & 0 & 3 & 3 \\
Blistering & 1 & 0 & 0 & 0 & 0 & 0 & 0 & 1 & 0 & 0 & 0 & 0 & 0 & 0 & 0 & 0 & 0 & 0 & 0 & 0 & 0 & 0 \\
Chalking & 0 & 0 & 1 & 2 & 1 & 2 & 1 & 3 & 3 & 1 & 1 & 1 & 2 & 1 & 1 & 1 & 1 & 1 & 2 & 0 & 0 & 1 \\
Incisión (blist.) & 0 & 2 & 1 & 0 & 0 & 0 & 0 & 0 & 2 & 0 & 0 & 0 & 0 & 1 & 1 & 1 & 1 & 1 & 0 & 0 & 0 & 0 \\
Fungus & 0 & 0 & 0 & 0 & 5 & 5 & 0 & 5 & 0 & 1 & 1 & 4 & 0 & 0 & 0 & 1 & 1 & 1 & 1 & 0 & 1 & 0 \\
\hline
\end{tabular}

Table IV. Defects encountered on Group 3 specimens after 42 months of exposure in "El Pardo" testing station

Tabla IV. Defectos encontrados en las probetas del Grupo 3 después de 42 meses de exposición en la estación de "El Pardo"

\begin{tabular}{|c|c|}
\hline Identification & Defects \\
\hline $\begin{array}{l}\text { 1) Galvanized steel } \\
\text { (discontinuous) }\end{array}$ & $\begin{array}{l}\text { Coating corrosion products } \\
100 \% \text { rusting in the incision (light colouring) }\end{array}$ \\
\hline 2) Metallized (green) & $\begin{array}{l}\text { Discolouring of topcoat layer } \\
\text { No rusting in incision }\end{array}$ \\
\hline 3) Electroplated zinc & $\begin{array}{l}\text { Coating corrosion products } \\
\text { Corrosion at edges ( } 100 \%) \\
\text { Corrosion from incision (light colouring) }\end{array}$ \\
\hline $\begin{array}{l}\text { 4) Galvanized steel } \\
\text { (Sendzimir) }\end{array}$ & $\begin{array}{l}\text { Slight ( } 100 \%) \text { rusting at edges } \\
\text { Corrosion in incision (100\%) } \\
\text { Metallic shine (intense) }\end{array}$ \\
\hline 5) Galfán & $\begin{array}{l}\text { Slight corrosion at edges (100\%) } \\
\text { Corrosion in incision (100\%) light colouring } \\
\text { Metallic shine }\end{array}$ \\
\hline
\end{tabular}

Table V. Defects encountered on Group 4 specimens after 42 months of exposure in "El Pardo" testing station

Tabla V. Defectos encontrados en las probetas del Grupo 4 después de 42 meses de exposición en la estación de "El Pardo"

\begin{tabular}{ll}
\hline \multicolumn{1}{c}{ Materials } & \multicolumn{1}{c}{ Defects } \\
\hline a) Aluminized & Corrosion at edges (100\%) \\
b) Metallized with $\mathrm{Al}$ & Corrosion at lower edge \\
C) Metallized with $\mathrm{Al} / \mathrm{Zn}$ & Corrosion in incision (100\%) \\
d) Galvalume (Al/Zn+Si) & Corrosion at edges \\
\hline
\end{tabular}

Table VI. Defects encountered on Group 5 specimens after 42 months of exposure in "El Pardo" testing station

Tabla VI. Defectos encontrados en las probetas del Grupo 5 después de 42 meses de exposición en la estación de "El Pardo"

\begin{tabular}{ll}
\hline Materials/Identification & \multicolumn{1}{c}{ Defects } \\
\hline Aluminium (AL) & Stains and soiling \\
Anodized Al & Shine (2) blistering (1) \\
Lacquered aluminium A $\left(^{*}\right)$ & Fungus (10) shine (2) \\
Lacquered aluminium B $\left(^{*}\right)$ & Fungus (0-2) shine (2) \\
Lacquered aluminium C $\left(^{*}\right)$ & Delamination in incision
\end{tabular}

* Specimen with and without incision.

group, noting slight losses of: colour, shine, chalking and also blistering in the incision. Fungus also appear on specimens $\mathrm{A}$ and $\mathrm{CH}$.

It is well known that degradation is suffered by all materials as a consequence of the action of the atmosphere, as a function of the macroclimate (oxygen, humidity, contamination, solar radiation) and microclimate (time of wetness of the surface, temperature of the material), surrounding the exposed specimen. Both the macroclimate and the microclimate play a decisive role in the durability of materials exposed to the action of the atmosphere.

This work evaluates the deterioration of metallic and organic coatings from the point of view of the protective function rather than the decorative function of the coatings.

The defects observed, considering the experimental results obtained after 42 months of exposure, are related with rusting in the incision on steel base specimens (in the other cases the zinc 
Table VIl. Defects encountered on Group 6 specimens after 42 months of exposure in "El Pardo" testing station Tabla VII. Defectos encontrados en las probetas del Grupo 6 después de 42 meses de exposición en la estación de "El Pardo"

\begin{tabular}{|c|c|c|c|c|c|c|c|c|c|c|c|c|}
\hline \multirow{2}{*}{ Defects } & \multicolumn{11}{|c|}{ Identification of coatings/Degree of deterioration (ISO) } & \multirow[b]{2}{*}{ E4 } \\
\hline & A1 & A2 & A3 & A4 & A5 & A6 & $\mathrm{CH} 1$ & $\mathrm{CH} 2$ & E1 & E2 & E3 & \\
\hline Colour & 2 & 2 & 2 & 2 & 2 & 0 & 0 & 0 & 0 & 0 & 0 & 0 \\
\hline Shine & 1 & 1 & 1 & 1 & 1 & 1 & 0 & 3 & 0 & 0 & 0 & 0 \\
\hline Chalking & 0 & 0 & 0 & 0 & 0 & 0 & 1 & 0 & 0 & 0 & 0 & 1 \\
\hline Incision (blist.) & 2 & 0 & 0 & 2 & 2 & 0 & 2 & 2 & 0 & 0 & 0 & 0 \\
\hline Fungus & 1 & 0 & 0 & 0 & 0 & 0 & 2 & 0 & 0 & 0 & 0 & 0 \\
\hline
\end{tabular}

affords cathodic protection); slight losses of colour, shine and chalking on organic coatings. On the other hand the most generalized defect in the metallic coatings has been corrosion in the incision and at the bare edges. The field study has been conditioned by the effect of the low corrosivity of the atmosphere.

\section{CONCLUSION}

In general, after 42 months of exposure in the rural atmosphere a minimum degree of degradation (in many cases almost nil) of both the organic and metallic coatings is observed. "El Pardo" testing station may be considered a reference station in view of its low aggressiveness and the slight deterioration experienced by all the specimens exposed, even at the lowest thicknesses.

\section{Acknowledgements}

The authors would like to thank the rest of the working team at CENIM for their assistance, namely Dr. José Antonio González Fernández, Dr. Eduardo Otero Soria and Miguel A. Castadot Pradera. They also thank CYTED for the economic assistance that has made it possible to carry out this project, and finally the Colombian Institute for the Development of Science and Technology "Francisco José de Caldas" (COLCIENCIAS) for the doctoral scholarship granted to Juan G. Castaño.

\section{REFERENCES}

[1] M. Morcillo, E. Almeida, B. Rosales, J. Uruchurtu and M. MARrocos (Eds.), Corrosión y protección en las atmósferas de iberoamérica. Parte I: Mapas de Iberoamerica de Corrosividad Atmosférica (Proyecto MICAT /CYTED), CYTED, Madrid, 1999, pp. 1-52.

[2] M. Morcillo and J. Simancas, Pint. Acabados Ind. 36216 (1994) 9-17.

[3] L. Odnevall and C.J. Leygraf, Electrochem. Soc. 14211 (1995) 3.682-3.689.

[4] D. Pereira, O. Nobre and E. Almeida, Progress in the Understanding and Prevention of Corrosion, Organising body, Barcelona, 1993.

[5] M. Morcillo, S. Feliu and J. SimanCAS, Farbe + Lack. 95 10 (1989) 726-728.

[6] M. Morcillo, Proc.14 $4^{\text {th }}$ International Corrosion Congress, International Corrosion Council (ICC), Cape Town, South Africa, 1999.

[7] ISO 9223: Corrosion of metals and alloys. Classification of corrosivity of atmospheres, International Standards Organization, Switzerland,1994.

[8] ISO 2810/74: Paints and varnishes. Notes for guidance on conduct of natural weathering tests, International Standards Organization, Switzerland, 1974, pp. 394- 400.

[9] ISO 4628-1 to 6: Paints and varnishes. Evaluation of degradation of paint coating- Designation of intensity, quantity and size of common types of defect, International Standards Organization, Switzerland, 1982, pp. 524-548. 